\title{
The Impact of Nutritional and Lifestyle Changes on Body Weight, Body Composition and Cardiometabolic Risk Factors in Children and Adolescents during the Pandemic of COVID-19: A Systematic Review
}

\author{
Kalliopi Karatzi ${ }^{+}{ }^{\mathbb{D}}$, Kalliopi-Anna Poulia ${ }^{+}$(D) , Emilia Papakonstantinou ${ }^{\mathbb{D}}$ and Antonis Zampelas * (D) \\ Laboratory of Dietetics and Quality of Life, Department of Food Science and Human Nutrition, \\ Agricultural University of Athens, Iera Odos 75, 11855 Athens, Greece; pkaratzi@aua.gr (K.K.); \\ lpoulia@gmail.com (K.-A.P.); apapakonstantinou@gmail.com (E.P.) \\ * Correspondence: azampelas@aua.gr; Tel.: +30-210-5294701 \\ + These authors contributed equally to this work.
}

check for updates

Citation: Karatzi, K.; Poulia, K.-A.; Papakonstantinou, E.; Zampelas, A. The Impact of Nutritional and Lifestyle Changes on Body Weight, Body Composition and Cardiometabolic Risk Factors in Children and Adolescents during the Pandemic of COVID-19: A Systematic Review. Children 2021, 8, 1130.

https://doi.org/10.3390/

children 8121130

Received: 12 November 2021

Accepted: 29 November 2021

Published: 4 December 2021

Publisher's Note: MDPI stays neutral with regard to jurisdictional claims in published maps and institutional affiliations.

Copyright: (c) 2021 by the authors. Licensee MDPI, Basel, Switzerland. This article is an open access article distributed under the terms and conditions of the Creative Commons Attribution (CC BY) license (https:// creativecommons.org/licenses/by/ $4.0 /)$.

\begin{abstract}
The coronavirus (COVID-19) pandemic and the measures taken by most countries to curb virus transmission, such as social distancing, distance learning, population, home confinement and disruption of all organized activities, has affected children and adolescents worldwide. The aim of this review was to assess the role of diet and lifestyle changes due to COVID-19 measures on body weight/composition and cardiometabolic risk factors in children and adolescents. An electronic search was conducted in PUBMED, COCHRANE, Google Scholar and SCOPUS databases up to 31 October 2021. 15 eligible studies were identified. According to the studies included in the analysis, COVID-19 measures seem to have had a negative impact on the diets and lifestyles of children and adolescents, with a consequent increase in body weight and central fat accumulation. On the other hand, the parental presence and control resulted in better glycaemic control in children with diabetes mellitus (DM) Type 1, but the effect of the pandemic in the glycaemic control of children with DM2 2 is controversial. Finally, diet and lifestyle changes had a differential impact on children's hypertension prevalence. These findings point to the need for public policy measures to prevent obesity and its complications, to and improve diet and lifestyle during the continuing and yet unresolved COVID-19 epidemic.
\end{abstract}

Keywords: diet; lifestyle; body composition; cardiometabolic risk; children; adolescents; COVID-19

\section{Introduction}

Coronavirus disease (COVID-19) caused by the severe acute respiratory syndrome coronavirus 2 (SARS-CoV-2) is one of the most serious pandemics worldwide that has infected and killed millions of people. To curb virus transmission, several preventive measures have been taken by most of the countries on all continents, such as the limitation of travelling, distance learning in all educational levels, tele-working, and total confinement of the general population at home. These measures, also known as lockdown, caused disruption of daily activities in all ages due to the need for social distancing to control the epidemiology of the disease [1].

Some of the major consequences of the pandemic measures, such as social distancing and the shutdown of live educational activities have affected lifestyle and dietary behaviors related to overall health in both children and their families. Interestingly it was suggested that the lockdown is responsible for the consumption of poor-quality food, such as ultraprocessed, calorie-dense comfort food when compared to standard living conditions [2,3]. The abrupt interruption of organized physical activities such as sports are paralleled with increased sedentary habits and screen time due to the inability to perform social gathering, distance learning, cancellation of the function of recreation programs and playgrounds and 
confinement at home. These changes have also affected sleep quality and duration. More specifically, the cancelation of live participation in educational activities attenuated all unfavorable consequences, as school increases opportunities for structured and recreational physical activities, decreases screen time, reduces opportunities for snacking and enables earlier school-day bedtimes [4]. Therefore, children's social distancing enhanced feelings of boredom and stress, increased snacking of energy-dense foods and emotional eating, and at the same time reduced the participation in structured physical activities, and increased sedentary time and inadequate or low quality sleep time [5]. The consequent disproportion between energy intake and energy spent inevitably resulted in a positive energy balance, increased fat disposition and weight gain [2,6].

Childhood obesity is another epidemic and it is considered as the most important health problem of the 21st century concerning 38 million children under the age of 5 , and over 340 million children and adolescents aged 5-19 [7,8]. It has a multi-factorial origin with genes, perinatal factors, social setting background, obesogenic environment, and lifestyle habits/dietary preferences, physical activity, sedentary time and sleep duration playing the most important roles [6].

The measures implemented due to the COVID-19 pandemic have created an obesogenic environment in children with less physical activity, longer sedentary time, unhealthy and energy dense food choices and sleep disturbances, which has probably led to even higher childhood obesity prevalence [9]. In turn, childhood obesity amplifies the risk of cardiometabolic conditions such as hypertension, dyslipidemia, diabetes and cardiovascular disease (CVD) [10-12]. At the same time, healthy food choices and regular physical activity are also considered to play a significant role in health in the early stages of life, which can also lower the risk of developing non-communicable (NCDs) diseases in adulthood [8].

These unprecedented living conditions, with confinement at home, increased food consumption and sedentary time during the day, may have led to significant alterations in body composition and body weight, as well as in deterioration of cardiometabolic health. As the COVID-19 pandemic remains a resisting and unresolved health problem, it continues to affect children's lives and overall health.

Therefore, the aim of this systematic review was to collect and critically evaluate all the available scientific work related to the interplay between diet and lifestyle changes and children's body composition and cardiometabolic risk during the COVID-19 pandemic, in order to enable public health initiatives for the prevention of the negative consequences of obesity and cardiometabolic risk early in life.

\section{Materials and Methods}

The present review was registered and published by PROSPERO, under the title "Systematic review of the role of lifestyle and diet on body composition changes and cardiometabolic risk factors in children during the pandemic of COVID-19" (registration number: CRD42021279972). The present work was prepared and presented in accordance with the guidelines of the PRISMA statements.

\subsection{Search Strategy}

A systematic search for eligible studies was performed through October 2021 by two separate reviewers on the PUBMED, COCHRANE, Google Scholar and SCOPUS databases using identical language, age, and date limits. The last day of searches in all mentioned databases was 31 October. Search keywords and medical subject headings (MESH terms) applied were: [("diet" or "dietary" or "lifestyle") and ("body composition" or "body weight" or "weight status" or "weight change" or "BMI" or "waist circumference" or "childhood obesity" or "children overweight/obese") or ("cardiometabolic" or "cardiovascular" or "hyperlipidemia" or "dyslipidemia" or "hypertension" or "diabetes" or "metabolic syndrome"]. Studies were limited to the English language and human studies in children aged 0-18 years. Reference lists and related articles of included studies were also examined for additional relevant articles (Figure 1). 


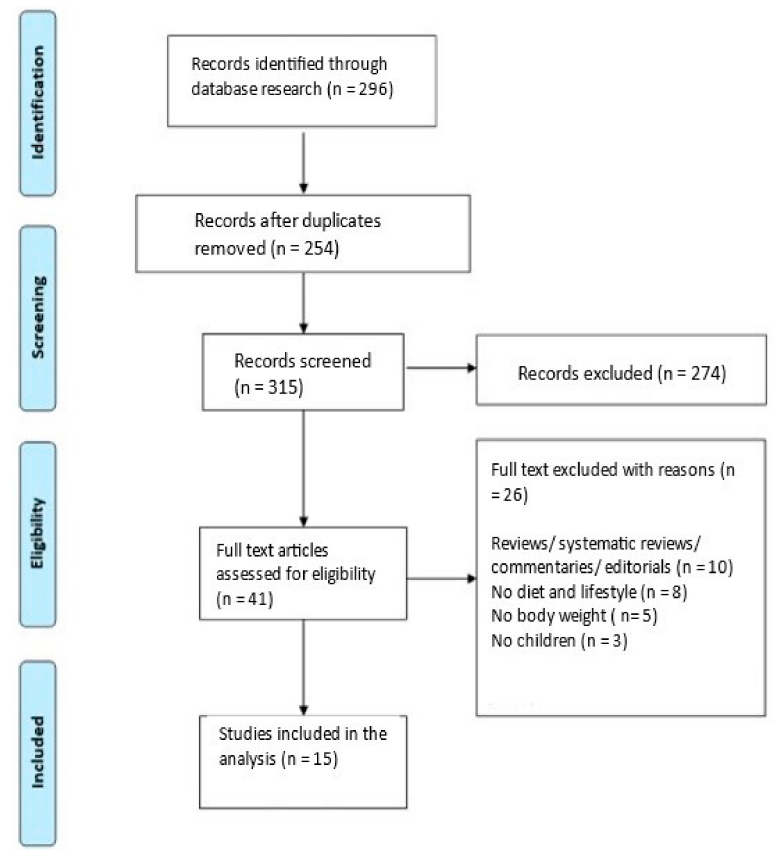

Figure 1. PRISMA flow chart of included studies.

\subsection{Eligibility Criteria}

The studies that were decided to be included in the review were examining the possible role of diet and lifestyle changes on children's body composition and cardiometabolic conditions. The inclusion criteria applied were peer-reviewed, epidemiological studies or clinical trials, English language, human studies, children 0-18 years of age, published from the year 2020 and onwards, with clear results regarding changes in body weight/body composition or parameters related to cardiometabolic health. The following exclusion criteria were applied: studies conducted in adults, animal studies, reviews, systematic reviews, meta-analyses, commentaries/letters and editorials.

\subsection{Selection of Studies and Data Extraction}

Two reviewers performed independent research in the databases mentioned before, for titles and abstracts of all the relative resources. The search results were then imported to EndNote Software for identification and removal of all duplicates. Afterwards the two reviewers removed articles according to eligibility criteria in order to determine the final number of studies to be included in the review. Discrepancies were resolved after discussion. After agreement, full text screening was carried out. Qualitative and quantitative data from all included articles were extracted by both reviewers. The extracted data included specific details for study design, population characteristics, assessment methods used and changes in diet, lifestyle, body composition or body weight and cardiometabolic conditions.

\subsection{Risk of Bias}

A risk of bias tool was conducted with the Revised Cochrane risk-of-bias tool for randomized trials (RoB 2) [13]. The risk of bias covered the six domains of bias as described in the tool: election bias, performance bias, detection bias, attrition bias, reporting bias, and other bias. Relative plots were created for all the studies included in the analysis (Figures 2 and 3).

\section{Results}

The initial search identified 296 references (Figure 1). After scanning for potential duplicates, 42 references were excluded. The remaining 254 references were screened according to title/abstract and reference lists, and relevant articles were screened. These procedures resulted in 315 references screened for relevance, out of which 274 were excluded. The remaining 41 articles underwent a full-text review based on inclusion and 
exclusion criteria. Further to this, 26 articles were excluded due to article type (editorials, commentaries or irrelevant reviews, $N=10$ ) or due to inclusion/exclusion criteria, absence of diet and/or lifestyle outcomes $(N=8)$, absence of body composition/body weight outcomes $(N=5)$ adult population $(N=3)$. The final number of studies included in the present review is 15. These studies are summarized in Tables 1 and 2.

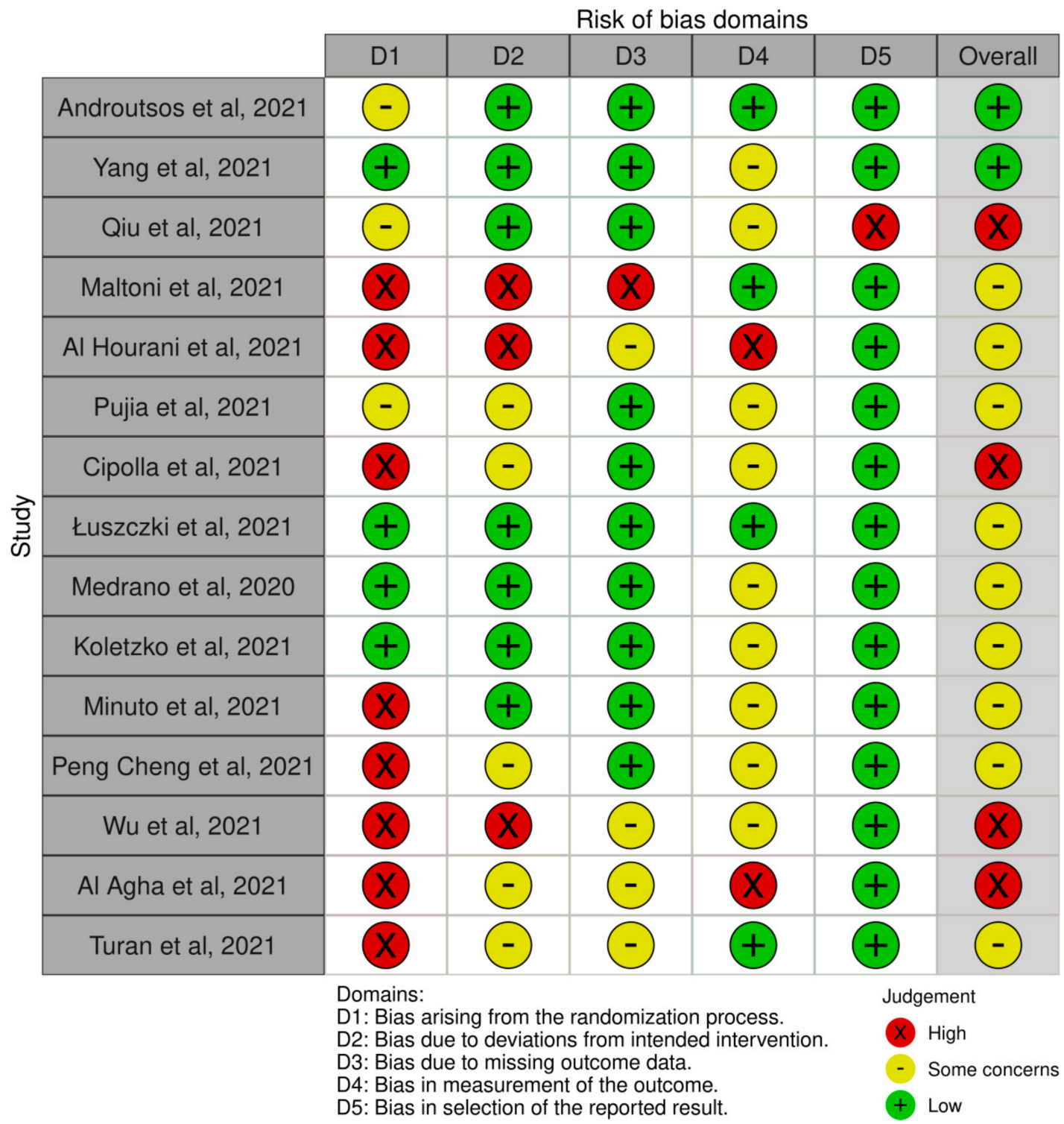

Figure 2. Studies with the representation of the Domains of risk of Bias.

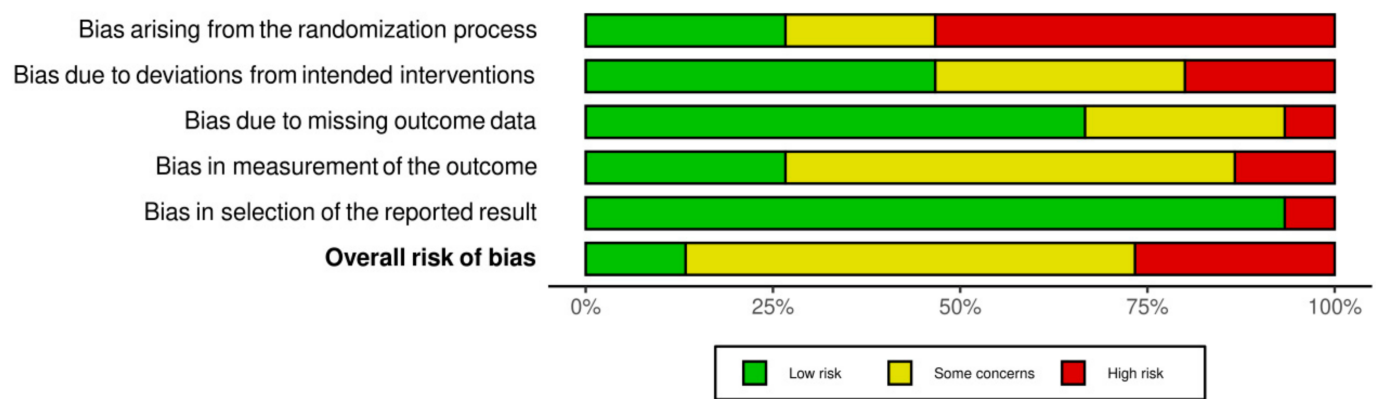

Figure 3. Overall presentation of the domains of risk among the studies. 
Table 1. Characteristics of studies regarding the role of diet and lifestyle changes on body weight and body composition.

\begin{tabular}{|c|c|c|c|c|c|c|c|c|c|}
\hline Identity & Country & Study Design & Participants (N) & Age Range (Years) & Diet Assessment & $\begin{array}{l}\text { Lifestyle } \\
\text { Assessment }\end{array}$ & $\begin{array}{l}\text { Anthropometry and } \\
\text { Body Composition } \\
\text { Assessment }\end{array}$ & $\begin{array}{l}\text { Outcome in Diet and } \\
\text { Lifestyle }\end{array}$ & $\begin{array}{l}\text { Outcome in Body } \\
\text { Composition }\end{array}$ \\
\hline $\begin{array}{l}\text { Androutsos et al., } \\
2021 \text { [14] }\end{array}$ & Greece & $\begin{array}{l}\text { Cross sectional } \\
\text { Online survey }\end{array}$ & 397 & $2-18$ & $\begin{array}{l}\text { Questionnaire for } \\
\text { the dietary habits of } \\
\text { parents and children }\end{array}$ & $\begin{array}{l}\text { Questionnaire on } \\
\text { Sleep duration } \\
\text { Screen time and } \\
\text { Physical activity }\end{array}$ & $\begin{array}{l}\text { Self-reported weight } \\
\text { and height }\end{array}$ & $\begin{array}{l}\uparrow \text { sleep duration } \\
\uparrow \text { screen time } \downarrow \\
\text { physical activity } \\
\downarrow \text { fast food } \\
\uparrow \text { fruit and vegetables } \\
\uparrow \text { breakfast }\end{array}$ & $\begin{array}{l}\uparrow \text { Body weight in } 35 \% \text { of } \\
\text { the participants }\end{array}$ \\
\hline Yang et al., 2020 [15] & China & Retrospective study & 10,082 & $16-18$ & $\mathrm{~N} / \mathrm{A}$ & $\begin{array}{l}\text { Physical activity } \\
\text { Questionnaire } \\
\text { (IPAQ) long form }\end{array}$ & $\begin{array}{l}\text { Self-reported weight } \\
\text { and Height } \\
\text { BMI }\end{array}$ & $\begin{array}{l}\downarrow \text { physical activity } \\
\text { frequency and } \\
\text { intensity } \\
\uparrow \text { screen time }\end{array}$ & $\begin{array}{l}\uparrow \text { BMI } \\
\uparrow \% \text { Overweight/Obesity }\end{array}$ \\
\hline Qiu et al., 2021 [16] & China & Cohort study & 445 & $7-12$ & $\begin{array}{l}\text { Questionnaire } \\
\text { on diet }\end{array}$ & $\begin{array}{l}\text { Questionnaires on } \\
\text { lifestyle }\end{array}$ & $\begin{array}{l}\text { Measured weight } \\
\text { and Height }\end{array}$ & N/A & $\uparrow \%$ Overweight/Obesity \\
\hline Maltoni et al., 2021 [17] & Italy & Cross sectional & 51 & $10-18$ & $\begin{array}{l}\text { Questionnaire on } \\
\text { nutrition }\end{array}$ & $\begin{array}{l}\text { Physical activity } \\
\text { Questionnaire } \\
\text { (IPAQ) sort form }\end{array}$ & $\begin{array}{l}\text { Measured weight and } \\
\text { Height } \\
\text { Waist circumference }\end{array}$ & $\begin{array}{l}\uparrow \text { Sedentary behavior } \\
\downarrow \text { Physical activity }\end{array}$ & $\begin{array}{l}\uparrow \text { BMI } \\
\uparrow \text { Waist circumference } \\
\uparrow \text { Weight } \\
\uparrow \text { Weight/height ratio }\end{array}$ \\
\hline $\begin{array}{l}\text { Al Hourani et al., } \\
2021 \text { [18] }\end{array}$ & Jordan & Cross sectional & 477 & $6-17$ & FFQ & $\begin{array}{l}\text { Questionnaire on } \\
\text { Screen time and } \\
\text { Physical activity }\end{array}$ & $\begin{array}{l}\text { Self-reported weight } \\
\text { and height } \\
\text { BMI for age Z scores }\end{array}$ & $\begin{array}{l}\uparrow \text { Screen time } \\
\uparrow \text { Sedentary } \\
\uparrow \text { Dietary intake }\end{array}$ & $\begin{array}{l}\uparrow \text { BMI for age } Z \text { score } \\
\uparrow \text { Body Weight }\end{array}$ \\
\hline Pujia et al., 2021 [19] & Italy & $\begin{array}{l}\text { Cross sectional } \\
\text { Online survey }\end{array}$ & 439 & $5-14$ & $\begin{array}{l}\text { Questionnaire on } \\
\text { eating habits }\end{array}$ & $\begin{array}{l}\text { Questionnaire on } \\
\text { physical activity }\end{array}$ & $\begin{array}{l}\text { Self-reported weight } \\
\text { and height } \\
\text { BMI }\end{array}$ & $\begin{array}{l}\uparrow \text { Comfort food intake } \\
\text { (chocolate, sweet } \\
\text { snacks, and deserts } \\
\uparrow \text { pizza and } \\
\text { bakery products } \\
\downarrow \text { sweetened beverages } \\
\text { and candies } \\
\uparrow \text { sedentary lifestyle } \\
\text { in adolescents }\end{array}$ & $\begin{array}{l}\uparrow \text { Body Weight in } 59.7 \% \\
\text { of the participants } \\
\uparrow \text { BMI }\end{array}$ \\
\hline Cipolla et al., 2021 [20] & Italy & $\begin{array}{l}\text { Cross sectional } \\
\text { Telephone } \\
\text { interview }\end{array}$ & 64 & $8-18$ & $\begin{array}{l}\text { Questionnaire on } \\
\text { eating habits }\end{array}$ & $\begin{array}{l}\text { Questionnaire on } \\
\text { physical activity }\end{array}$ & $\begin{array}{l}\text { Measured weight } \\
\text { and height }\end{array}$ & $\begin{array}{l}\uparrow \text { pizza and } \\
\text { bakery products } \\
\uparrow \text { sedentary lifestyle } \uparrow \\
\text { Screen time }\end{array}$ & $\uparrow \mathrm{BMI}$ \\
\hline $\begin{array}{l}\text { Łuszczki et al., } \\
2021[21]\end{array}$ & Poland & Cross sectional & 1016 & $6-15$ & FFQ-6 & $\begin{array}{l}\text { Sleep quality and } \\
\text { durationScreen } \\
\text { timeSelf-reported } \\
\text { physical activity }\end{array}$ & $\begin{array}{l}\text { Measured weight } \\
\text { and height } \\
\text { BMI }\end{array}$ & $\begin{array}{l}\downarrow \text { Sleep duration } \\
\uparrow \text { Sleep quality } \\
\downarrow \text { Physical activity } \\
\uparrow \text { Screen time } \\
\downarrow \text { fruit juices, } \\
\text { carbonated sugar } \\
\text { sweetened/diet drinks, } \\
\text { meats } \downarrow \text { canned food, } \\
\text { fast f ood, snacks } \\
\uparrow \text { protein intake } \\
\uparrow \text { sweets }\end{array}$ & Non-significant changes \\
\hline
\end{tabular}


Table 1. Cont.

\begin{tabular}{|c|c|c|c|c|c|c|c|c|c|}
\hline Identity & Country & Study Design & Participants (N) & Age Range (Years) & Diet Assessment & $\begin{array}{l}\text { Lifestyle } \\
\text { Assessment }\end{array}$ & $\begin{array}{l}\text { Anthropometry and } \\
\text { Body Composition } \\
\text { Assessment }\end{array}$ & $\begin{array}{l}\text { Outcome in Diet and } \\
\text { Lifestyle }\end{array}$ & $\begin{array}{l}\text { Outcome in Body } \\
\text { Composition }\end{array}$ \\
\hline $\begin{array}{l}\text { Medrano et al., } \\
2020 \text { [22] }\end{array}$ & Spain & $\begin{array}{l}\text { Longitudinal } \\
\text { cohort study } \\
\text { (MUGI project) }\end{array}$ & 291 & $8-16$ & $\begin{array}{l}\text { Adherence to } \\
\text { Mediterranean diet } \\
\text { (KIDMED) }\end{array}$ & $\begin{array}{l}\text { Physical Activity } \\
\text { and screen time } \\
\text { during leisure were } \\
\text { assessed by } \\
\text { "The Youth } \\
\text { Activity Profile" } \\
\text { questionnaire (YAP) }\end{array}$ & $\begin{array}{l}\text { Measured Height } \\
\text { and Weight } \\
\text { BMI } \\
\text { Body Composition } \\
\text { (BIA) } \\
\text { Waist circumference }\end{array}$ & $\begin{array}{l}\downarrow \text { Physical activity } \\
\uparrow \text { Screen time } \\
\uparrow \text { KIDMED score }\end{array}$ & Non-significant changes \\
\hline $\begin{array}{l}\text { Koletzko et al., } \\
2021 \text { [23] }\end{array}$ & Germany & $\begin{array}{l}\text { Cross sectional } \\
\text { Online survey }\end{array}$ & $\begin{array}{l}1000 \text { parents } \\
\text { with at least } 1 \\
\text { child }<14 \mathrm{y} \\
\text { living in the } \\
\text { same household }\end{array}$ & $0-14$ & $\begin{array}{l}\text { Questionnaire on } \\
\text { diet habits }\end{array}$ & $\begin{array}{l}\text { Questionnaire on } \\
\text { Physical activity }\end{array}$ & $\begin{array}{l}\text { Self-reported } \\
\text { weight gain }\end{array}$ & $\begin{array}{l}\uparrow \text { Fruit and Vegetables } \\
\uparrow \text { Carbohydrates } \\
\uparrow \text { Salty/sweet snacks } \\
\uparrow \text { Soft drinks } \\
\downarrow \text { Physical activity } \\
\uparrow \text { cooking at home }\end{array}$ & $\begin{array}{l}\uparrow \text { Body weight in } 9 \% \text { of } \\
\text { the children }\end{array}$ \\
\hline
\end{tabular}

BMI: Body Mass Index, FFQ: Food Frequency Questionnaire, N/A: non applicable, $\uparrow$ increase, $\downarrow$ decrease, $\uparrow \%$ increased percentage of patients, $\downarrow \%$ decreased percentage of patients.

Table 2. Study characteristics regarding the role of diet and lifestyle changes on cardiometabolic conditions.

\begin{tabular}{|c|c|c|c|c|c|c|c|c|c|}
\hline Identity & Country & Study Design & Participants (N) & Age Range (Years) & Diet Assessment & $\begin{array}{l}\text { Lifestyle } \\
\text { Assessment }\end{array}$ & $\begin{array}{l}\text { Cardiometabolic } \\
\text { Risk Factors }\end{array}$ & $\begin{array}{l}\text { Outcome in Diet } \\
\text { and Lifestyle }\end{array}$ & $\begin{array}{l}\text { Outcome in } \\
\text { Cardiometabolic } \\
\text { Risk Factors }\end{array}$ \\
\hline Qiu et al., 2021 [16] & China & Cohort study & 445 & $7-12$ & $\begin{array}{l}\text { Questionnaire } \\
\text { on diet }\end{array}$ & $\begin{array}{l}\text { Questionnaires } \\
\text { on lifestyle }\end{array}$ & $\begin{array}{l}\text { Blood pressure } \\
\text { measured }\end{array}$ & N/A & $\begin{array}{l}\uparrow \% \text { with Elevated } \\
\text { Blood pressure }\end{array}$ \\
\hline Maltoni et al., 2021 [17] & Italy & Cross sectional & 51 & $10-18$ & $\begin{array}{l}\text { Questionnaire } \\
\text { on nutrition }\end{array}$ & $\begin{array}{l}\text { Physical activity } \\
\text { Questionnaire } \\
\text { (IPAQ) sort form }\end{array}$ & Blood pressure & $\begin{array}{l}\uparrow \text { Sedentary behavior } \\
\downarrow \text { Physical activity }\end{array}$ & $\begin{array}{l}\downarrow \% \text { with Elevated } \\
\text { blood pressure }\end{array}$ \\
\hline Minuto et al., 2021 [24] & Italy & $\begin{array}{l}\text { Retrospective } \\
\text { observational } \\
\text { cohort study }\end{array}$ & $\begin{array}{l}202 \\
101(0-18) \\
\text { with T1DM }\end{array}$ & $6-39$ & N/A & $\begin{array}{l}\text { Self-reported } \\
\text { physical activity }\end{array}$ & $\begin{array}{l}\text { GCM for glucose } \\
\text { monitoring } \\
\text { HbA1c }\end{array}$ & $\downarrow$ Physical activity & $\begin{array}{l}\text { Improved } \\
\text { glycemic control }\end{array}$ \\
\hline $\begin{array}{l}\text { Peng Cheng et al., } \\
2021 \text { [25] }\end{array}$ & Malaysia & Cross sectional & $\begin{array}{l}123 \\
\text { (93 patients with } \\
\text { T1DM and } 30 \\
\text { with T2DM) }\end{array}$ & $0-18$ & $\begin{array}{l}\text { Standardized } \\
\text { questionnaire for } \\
\text { diet and lifestyle }\end{array}$ & $\begin{array}{l}\text { Standardized } \\
\text { questionnaire } \\
\text { for lifestyle } \\
\text { Physical activity } \\
\text { assessment with } \\
\text { PAQ-C for children } \\
\text { and PAQ-A for } \\
\text { older children; }\end{array}$ & $\mathrm{HbA1c}$ & $\begin{array}{l}\downarrow \text { meal frequency } \\
\text { (skipping breakfast) } \\
\downarrow \text { physical activity } \\
\uparrow \text { screen time } \\
\uparrow \text { sleep duration }\end{array}$ & $\begin{array}{l}\uparrow \text { HbA1c in T2DM and } \\
\text { pubertal adolescents } \\
\downarrow \text { HbA1c in pre-pubertal } \\
\text { T1DM children } \\
\uparrow \text { Weight and BMI SDS } \\
\text { in T1DM } \\
\downarrow \text { Weight and BMI SDS } \\
\text { in T2DM }\end{array}$ \\
\hline
\end{tabular}


Table 2. Cont.

\begin{tabular}{|c|c|c|c|c|c|c|c|c|c|}
\hline Identity & Country & Study Design & Participants (N) & Age Range (Years) & Diet Assessment & $\begin{array}{l}\text { Lifestyle } \\
\text { Assessment }\end{array}$ & $\begin{array}{l}\text { Cardiometabolic } \\
\text { Risk Factors }\end{array}$ & $\begin{array}{l}\text { Outcome in Diet } \\
\text { and Lifestyle }\end{array}$ & $\begin{array}{l}\text { Outcome in } \\
\text { Cardiometabolic } \\
\text { Risk Factors }\end{array}$ \\
\hline Wu et al., 2021 [26] & China & $\begin{array}{l}\text { Observational study } \\
\text { Telephone interview }\end{array}$ & 43 with T1DM & $0-18$ & $\begin{array}{l}\text { Questionnaire for } \\
\text { dietary intake }\end{array}$ & $\begin{array}{l}\text { Questionnaire for, } \\
\text { physical exercise, } \\
\text { sleep habits } \\
\text { and emotions }\end{array}$ & $\begin{array}{l}\text { GCM for glucose } \\
\text { monitoring } \\
\text { HbA1c }\end{array}$ & $\begin{array}{l}\uparrow \text { number of snacks, } \\
\uparrow \text { sleep duration } \\
\uparrow \text { time for diabetes } \\
\text { management } \\
\downarrow \text { physical activity }\end{array}$ & $\begin{array}{l}\text { No significant } \\
\text { changes }\end{array}$ \\
\hline $\begin{array}{l}\text { Al Agha et al., } \\
2021 \text { [27] }\end{array}$ & Saudi Arabia & $\begin{array}{l}\text { Cross sectional } \\
\text { study }\end{array}$ & 150 with T1DM & $2-18$ & $\begin{array}{l}\text { Questionnaire for } \\
\text { dietary habits }\end{array}$ & $\begin{array}{l}\text { Questionnaire for } \\
\text { physical activity } \\
\text { and mood }\end{array}$ & $\begin{array}{l}\text { Blood pressure } \\
\text { (systolic and } \\
\text { diastolic) } \\
\text { HbA1c } \\
\text { CGM } \\
\end{array}$ & $\begin{array}{l}\downarrow \text { physical activity } \\
\uparrow \text { consumption of } \\
\text { carbohydrates and } \\
\text { fast food } \\
\downarrow \text { mood }\end{array}$ & $\begin{array}{l}\uparrow \mathrm{HbA} 1 \mathrm{c} \\
\uparrow \mathrm{BMI} \uparrow \\
\text { Blood pressure }\end{array}$ \\
\hline Turan et al., 2021 [28] & Turkey & Cross sectional & 100 with T1DM & $3-18$ & $\begin{array}{l}\text { Questionnaire on } \\
\text { snack and meal } \\
\text { frequency, CHO } \\
\text { consumption }\end{array}$ & $\begin{array}{l}\text { Physical Activity } \\
\text { Questionnaire-A } \\
\text { (PAQ-A) or } \\
\text { Physical Activity } \\
\text { Questionnaire-C } \\
\text { (PAQ-C) }\end{array}$ & $\begin{array}{l}\text { HbA1c } \\
\text { BMI }\end{array}$ & $\begin{array}{l}\uparrow \text { consumption of } \\
\text { carbohydrates } \\
\text { Delayed sleep times }\end{array}$ & $\begin{array}{l}\uparrow \mathrm{HbA1c} \\
\downarrow \text { No of } \\
\text { hypoglycaemic } \\
\text { events }\end{array}$ \\
\hline
\end{tabular}

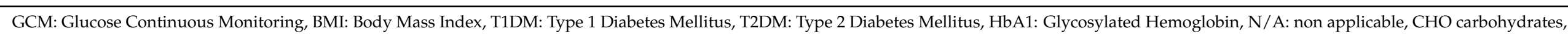

$\uparrow$ increase, $\downarrow$ decrease. $\uparrow \%$ increased percentage of patients, $\downarrow \%$ decreased percentage of patients. 


\subsection{Study Characteristics}

The studies included in the present systematic review regarding the role of diet and lifestyle on body composition/body weight (Table 1) originate from two continents, four from Asia $[15,16,18,29]$ and seven from Europe $[14,17,19-23]$. The included studies for the role of diet/lifestyle on cardiometabolic risk factors (Table 2) originate from three continents, one from the Middle East [27], four from Asia [16,25,26,28] and two from Europe [24,30]. Interestingly the countries included present with large variation in their socioeconomic status having both developed countries like Germany and developing countries like Malaysia. The age of the participants ranged from 0-18 years and the study sample varied from very small i.e., 43 volunteers, [26] to very large i.e., 10,000 participants [15]. Regarding the study methodology, there were 12 cross-sectional studies, two retrospective studies and one longitudinal study.

According to the risk assessment of the studies, it has been noted that most of them are rather small and are based on convenience sampling, with no actual randomization, and including self-reported measurements of height and weight. Therefore, the selection bias and the accuracy of the answers are questionable (Figure 1). Under this spectrum, the overall risk evaluation in Figure 3 presents to be in greater extent either moderate or high. There were also studies mentioning measurements without presenting the relative results. This fact can be attributed to the eagerness to publish results for a new and unknown situation and at the same time the difficulty of performing assessments in person due to the lockdown and the limited access to the healthcare facilities.

\subsection{Main Exposures}

Changes in body weight/body composition were evaluated in relation to measures of change in diet and/or lifestyle (Table 1). All studies used self-reported data either using known validated questionnaires such as the Food Frequency Questionnaire (FFQ) and the International Physical Activity Questionnaire (IPAQ), or other questionnaires collected either by phone, live interviews, or online surveys. The primary outcomes were changes in body weight, Body Mass Index (BMI) and waist circumference, which were either measured $(N=5)[16,17,20-22]$ or self-reported $(N=5)[14,15,18,19,23]$. Regarding the association of diet and/or lifestyle changes on cardiometabolic conditions, the primary outcome was blood pressure $(N=3)$ or glycemic control $(N=5)$.

\subsection{Studies on the Association of Diet and/or Lifestyle Changes on Body Weight/Body Composition}

The majority of studies assessed changes of both diet and lifestyle, except for two (one retrospective and one cross-sectional) which solely assessed parameters of physical activity and sedentary behavior [15,17]. Apart from one study that reported no results, [16] all the other included studies reported increased consumption of fats and fast foods, as well as processed food, sweet and salty snacks and sugar sweetened beverages. Yet some studies also reported increased consumption of breakfast, fruit and vegetable intake and reduction in fruit juice and carbonated drinks consumption. Also, all studies shown in Table 1 reported a significant decrease in physical activity paralleled with a significant increase in sedentary and screen time, while two studies assessing sleep duration and sleep quality as part of the lifestyle assessment presented with controversial results [14,21]. Regarding the changes in body weight/body composition, eight out of the 10 studies included in the analysis and presented in Table 1 reported significant increases in body weight, BMI, waist circumference or body fat, which was evident even in the $59.7 \%$ of the study population [14-19,23]. According to Qiu et al., 28.1\% of the children with normal BMI before the lockdown became overweight or obese, $42.4 \%$ of the overweight children became obese and $46.6 \%$ of the participants starting as normotensives presented abnormal $\mathrm{BP}$ levels at the end of the lockdown [16].

On the other hand, two studies reporting no changes in body weight/body composition measures during the pandemic also reported better adherence to the Mediterranean diet and reduced consumption of canned food, fast foods, snacks, fruit juices, sugar sweet- 
ened soft drinks and meat, resulting in an improved nutritional intake, an effect attributed to the increased family time and the time spent on cooking and meal preparation [21,22].

\subsection{Studies on the Association of Diet and/or Lifestyle Changes on Cardiometabolic Risk Factors}

Studies included in Table 2 presented outcomes regarding blood pressure and glycemic control, while no studies were retrieved for the association of diet and/or lifestyle changes during the pandemic with other cardiometabolic conditions. Regarding blood pressure, there are mixed results, as two studies reported increased blood pressure levels [16,27], while one study reported a relevant reduction [17], all paralleled with significant decreases in physical activity and increased time in sedentary behaviors. As regards glycaemic control studies, four studies were conducted solely in subjects with Type 1 diabetes mellitus (T1DM) [24,26-28] and one study included patients with both T1DM and type 2 diabetes mellitus (T2DM) [25]. Among them, two cross-sectional studies reported either increased plasma glucose levels by 18\% [27] or increased glycosylated haemoglobin A1c (HbA1c) [28] levels by $0.32 \%$, as a consequence of decreased physical activity, increased sedentary time and increased consumption of carbohydrates. Another cross-sectional study also reported elevated levels of sedentary behavior and decreased levels of physical activity together with altered meal frequency, mainly expressed as skipping breakfast. These dietary changes led to increased body weight and reduced $\mathrm{HbA} 1 \mathrm{c}$ in prepubertal T1DM children due to closed parental control of the management of blood glucose levels. At the same time, it was connected with decreased body weight and elevated levels of $\mathrm{HbA1c}$ in children with T2DM and pubertal adolescents, signs of uncontrolled diabetes mellitus [25]. In another small cross-sectional study, the decrease of hypoglycemic episodes was reported, with no change observed in $\mathrm{HbA} 1 \mathrm{c}$, despite the decreased physical activity and increased number of daily snacks [26]. Finally, in a retrospective observational study, an improvement in glycemic control was also reported in children with T1DM despite the increase of sedentary activities and the limitation of physical activity, mainly due to the closer control of the food intake and the glucose measurements from their parents [24].

\section{Discussion}

The impact of the COVID-19 pandemic on children has yet to be fully examined. There are justified concerns, confirmed by international organizations, that the health crisis that has emerged over the past two years may have severely affected the nutrition and lifestyles of children, with many unfavorable consequences with regard to childhood obesity and other cardiometabolic risks. Unfortunately, there are concerns that the COVID-19 pandemic threatens to reverse the hard-won progress achieved in the previous years in pediatric health.

The present systematic review aimed at gathering all existing knowledge from recently published articles regarding changes in diet and lifestyle during the COVID-19 pandemic and their effect on body weight and body composition, as well as cardiometabolic risk factors in children. These data may enable the design and implementation of public health preventive measures during periods of lockdown, particularly aiming at the enhancement of physical activity and healthy nutritional choices, especially when their duration is uncertain.

One of the main outcomes of the present systematic review is the fact that around the globe, similar dietary and lifestyle patterns were recorded [31,32]. The deterioration of food quality and the increment of food and energy quantity, alongside the mandatory confinement and the lower levels of physical activity and energy expenditure, combined to create an obesogenic environment for children. These changes were more profound in families with disadvantaged socioeconomic conditions, reflecting the economic impact of COVID-19 on nutrition and public health [33]. One of the main concerns is that these changes, which might be difficult to be reversed, can have short term and long-term negative effects on the overall health of the children in their childhoods and later on when they reach adulthood. 
The tele-education and the lockdown resulted in increased screen time spent on computers and mobile phones, not as recreation but also as an obligatory responsibility. As a result, physical activity levels were compromised, and sedentary time increased significantly in children and adolescents $[14,16,18,19,21,23]$. It has already been reported by previous studies that the amount of time spent engaged in sedentary activities during childhood and adolescence predicts overweight and obesity in adulthood [34], posing a reasonable concern of the possible effects of this pandemic on the obesity epidemics that we will have to face in the following years.

A significant modification to sleep quality and overall sleeping habits was reported in many of the included studies. Some studies reported increased sleeping hours [18,27,32], or decreased sleep duration but increased sleep quality [22], or delayed sleeping time at night [28], affecting several aspects of the health of children and adolescents. Insufficient or interrupted sleep relates to mood swings and attention problems and poor mental health, situations made worse during the COVID-19 pandemic [35]. Sufficient sleeping time is essential in childhood. The American Academy of Sleep Medicine recommends that toddlers (aged 3-5 years) should get 10-13 h of sleep per day, school-going children (ages 6-12 years) should get 9-12 h per night, and adolescents should get 8-10 h nightly [36]. During the confinement, most of the studies reported an increase in sleep duration, explained by the absence of the obligation to attend school and other activities, which was not always achieved during the confinement. Moreover, the flexibility in waking and bedtime hours was the reason for increased sleep duration [35]. However, as circadian disturbances relate to weight gain during school breaks, these changes may have an impact in weight gain in children during COVID-19 [4].

All reported alterations observed regarding diet and lifestyle habits seem to have worsened the already existing problem of bad lifestyle choices and pediatric obesity. It is noteworthy that in the pre-COVID 19 era, more than $80 \%$ of children around the world were inactive, more than $60 \%$ did not meet recommended screentime guidelines, and nearly a half have a scarce adherence to the Mediterranean diet [37-39]. If the assumption that this picture will worsen during the pandemic is correct, it will negatively affect children's current and future health, and many scientists express their fear that the COVID-19 pandemic might shift towards an obesity pandemic. It is essential that more studies should be carried out with the primary aim of measuring the impact of this pandemic on the nutritional habits and health status of children and adolescents in different contexts. One of the main goals of these studies should be to assess whether unhealthy nutritional habits are maintained in the long term or even improved, and to objectively assess children's nutritional parameters and compare them to the pre-pandemic era.

Another important aspect of the present review is the association of diet and lifestyle changes during the lockdown with cardiometabolic risk. Although the findings are controversial in some cases, there is limited evidence regarding worsening of glycemic control in children with T2DM and hypertension. On the contrary, the presence of parents and their active involvement in the management of T1DM resulted in a better management of children with T1DM. However, it is noteworthy that in most studies an increase in sweet and salty snacks, as well as sugar sweetened beverages, was observed, pointing out an increase in sugar and sodium intake, which makes us skeptical regarding possible underestimated unfavorable consequences due to COVID-19 on glycaemic control and hypertension. However, due to limited evidence, the heterogeneity of studies and the varied quality more well-designed studies examining the effects of COVID-19 on glycaemic control and hypertension are needed to draw credible conclusions.

Moreover, adolescence is known to be an overwhelming time, with physical, hormonal, and behavioral changes that were made even more profound during lockdown, increasing the prevalence of anxiety, boredom, and lack of motivation. Stress can negatively affect blood glucose and blood pressure management, alongside with the unbalanced nutrient and energy equilibrium, resulting in poor diabetes control and blood pressure in children with T2DM. Therefore, the lifestyle and stress management in younger patients with 
diabetes is undoubtedly of paramount importance to maintaining good diabetes self-care, lower cardiometabolic risk and overall better health.

\section{Conclusions}

The COVID-19 pandemic that emerged in the past two years is still uncontrolled, and measures to curb virus infection, such as confinement at home and social distancing, lead to a disruption of daily activities with yet unknown health consequences. The present systematic review is the first to our knowledge that gathered existent relevant studies highlighting the worsening of children and adolescents' diet and lifestyle with unhealthy food choices, increased sedentary time, and decreased physical activities, which led to increased body weight and abdominal fat accumulation. Also, obesity, alongside with unhealthy diet and lifestyle with increased consumption of fat, sugar and sodium and increased time spent on sedentary activities are significant risk factors for cardiometabolic unfavorable consequences, such as diabetes and hypertension that are poorly studied or such as dyslipidemia and metabolic syndrome which are not studied at all, posing a great threat for an outburst of the existent obesity epidemic and its serious health implications. It is highly possible that the real consequences of COVID-19 on obesity and cardiometabolic conditions are understudied and possibly neglected, and therefore future public health initiatives are needed to assess and control obesity and its cardiometabolic complications in an early and timely fashion during this unprecedented public health crisis.

Author Contributions: K.K., K.-A.P., E.P. and A.Z. have contributed substantially to the work reported. In specific all authors contributed to conceptualization and methodology, K.K. and K.-A.P. performed the research, assessment of bias and data curation, and all the authors (K.K., K.-A.P., E.P. and A.Z.) contributed to the original draft preparation, writing, review and editing. All authors have read and agreed to the published version of the manuscript.

Funding: This research received no external funding.

Institutional Review Board Statement: Not applicable.

Informed Consent Statement: Not applicable.

Data Availability Statement: Not applicable.

Conflicts of Interest: The authors declare no conflict of interest.

\section{References}

1. WHO: Coronavirus Disease (COVID-19) Pandemic. Available online: https://www.who.int/emergencies/diseases/novelcoronavirus-2019 (accessed on 9 November 2021).

2. Ammar, A.; Brach, M.; Trabelsi, K.; Chtourou, H.; Bukhari's, O.; Masmoudi, L.; Bouaziz, B.; Bentlage, E.; How, D.; Ahmed, M.; et al. Effects of COVID-19 Home Confinement on Eating Behaviour and Physical Activity: Results of the ECLB-COVID19 International Online Survey. Nutrients 2020, 12, 1583. [CrossRef] [PubMed]

3. Jia, P.; Luo, M.; Li, Y.; Zheng, J.S.; Xiao, Q.; Luo, J. Fast-food restaurant, unhealthy eating, and childhood obesity: A systematic review and meta-analysis. Obes. Rev. 2021, 22, e12944. [CrossRef] [PubMed]

4. Baranowski, T.; O'Connor, T.; Johnston, C.; Hughes, S.; Moreno, J.; Chen, T.A.; Meltzer, L.; Baranowski, J. School year versus summer differences in child weight gain: A narrative review. Child. Obes. 2014, 10, 18-24. [CrossRef]

5. Di Renzo, L.; Gualtieri, P.; Pivari, F.; Soldati, L.; Attinà, A.; Cinelli, G.; Leggeri, C.; Caparello, G.; Barrea, L.; Scerbo, F.; et al. Eating habits and lifestyle changes during COVID-19 lockdown: An Italian survey. J. Transl. Med. 2020, 18, 229. [CrossRef] [PubMed]

6. Browne, N.T.; Snethen, J.A.; Greenberg, C.S.; Frenn, M.; Kilanowski, J.F.; Gance-Cleveland, B.; Burke, P.J.; Lewandowski, L. When Pandemics Collide: The Impact of COVID-19 on Childhood Obesity. J. Pediatr. Nurs. 2021, 56, 90-98. [CrossRef]

7. OECD; WHO. Overweight and Obesity. In Health at a Glance: Asia/Pacific 2020: Measuring Progress Towards Universal Health Coverage; OECD Publishing: Paris, France, 2020. [CrossRef]

8. NCD Risk Factor Collaboration. Worldwide trends in body-mass index, underweight, overweight, and obesity from 1975 to 2016 : A pooled analysis of 2416 population-based measurement studies in 128.9 million children, adolescents, and adults. Lancet 2017, 390, 2627-2642. [CrossRef]

9. Nogueira-de-Almeida, C.A.; Del Ciampo, L.A.; Ferraz, I.S.; Del Ciampo, I.R.L.; Contini, A.A.; Ued, F.D.V. COVID-19 and obesity in childhood and adolescence: A clinical review. J. Pediatr. 2020, 96, 546-558. [CrossRef] 
10. Flynn, J.T.; Kaelber, D.C.; Baker-Smith, C.M.; Blowey, D.; Carroll, A.E.; Daniels, S.R.; de Ferranti, S.D.; Dionne, J.M.; Falkner, B.; Flinn, S.K.; et al. Clinical Practice Guideline for Screening and Management of High Blood Pressure in Children and Adolescents. Pediatrics 2017, 140, e20171904. [CrossRef] [PubMed]

11. Deeb, A.; Attia, S.; Mahmoud, S.; Elhaj, G.; Elfatih, A. Dyslipidemia and Fatty Liver Disease in Overweight and Obese Children. J. Obes. 2018, 2018, 8626818. [CrossRef]

12. Pulgaron, E.R.; Delamater, A.M. Obesity and type 2 diabetes in children: Epidemiology and treatment. Curr. Diab. Rep. 2014, 14, 508. [CrossRef]

13. Sterne, J.A.C.; Savović, J.; Page, M.J.; Elbers, R.G.; Blencowe, N.S.; Boutron, I.; Cates, C.J.; Cheng, H.Y.; Corbett, M.S.; Eldridge, S.M.; et al. RoB 2: A revised tool for assessing risk of bias in randomised trials. BMJ 2019, 366, 14898. [CrossRef] [PubMed]

14. Androutsos, O.; Perperidi, M.; Georgiou, C.; Chouliaras, G. Lifestyle Changes and Determinants of Children's and Adolescents' Body Weight Increase during the First COVID-19 Lockdown in Greece: The COV-EAT Study. Nutrients 2021, 13, 930. [CrossRef] [PubMed]

15. Yang, S.; Guo, B.; Ao, L.; Yang, C.; Zhang, L.; Zhou, J.; Jia, P. Obesity and activity patterns before and during COVID-19 lockdown among youths in China. Clin. Obes. 2020, 10, e12416. [CrossRef]

16. Qiu, N.; He, H.; Qiao, L.; Ding, Y.; Ji, S.; Guo, X.; Luo, J.; Luo, Z.; Li, Y.; Pang, H.; et al. Sex differences in changes in BMI and blood pressure in Chinese school-aged children during the COVID-19 quarantine. Int. J. Obes. 2021, 45, 2132-2136. [CrossRef] [PubMed]

17. Maltoni, G.; Zioutas, M.; Deiana, G.; Biserni, G.B.; Pession, A.; Zucchini, S. Gender differences in weight gain during lockdown due to COVID-19 pandemic in adolescents with obesity. Nutr. Metab. Cardiovasc. Dis. 2021, 31, 2181-2185. [CrossRef]

18. Al Hourani, H.; Alkhatib, B.; Abdullah, M. Impact of COVID-19 Lockdown on Body Weight, Eating Habits, and Physical Activity of Jordanian Children and Adolescents. Disaster Med. Public Health Prep. 2021, 16, 1-9. [CrossRef] [PubMed]

19. Pujia, R.; Ferro, Y.; Maurotti, S.; Khoory, J.; Gazzaruso, C.; Pujia, A.; Montalcini, T.; Mazza, E. The Effects of COVID-19 on the Eating Habits of Children and Adolescents in Italy: A Pilot Survey Study. Nutrients 2021, 13, 2641. [CrossRef] [PubMed]

20. Cipolla, C.; Curatola, A.; Ferretti, S.; Giugno, G.; Condemi, C.; Delogu, A.B.; Birritella, L.; Lazzareschi, I. Eating habits and lifestyle in children with obesity during the COVID19 lockdown: A survey in an Italian center. Acta Biomed. 2021, 92, e2021196. [PubMed]

21. Łuszczki, E.; Bartosiewicz, A.; Pezdan-Śliż, I.; Kuchciak, M.; Jagielski, P.; Oleksy, Ł.; Stolarczyk, A.; Dereń, K. Children's Eating Habits, Physical Activity, Sleep, and Media Usage before and during COVID-19 Pandemic in Poland. Nutrients 2021, $13,2447$. [CrossRef]

22. Medrano, M.; Cadenas-Sanchez, C.; Oses, M.; Arenaza, L.; Amasene, M.; Labayen, I. Changes in lifestyle behaviours during the COVID-19 confinement in Spanish children: A longitudinal analysis from the MUGI project. Pediatr. Obes. 2021, 16, e12731. [CrossRef]

23. Koletzko, B.; Holzapfel, C.; Schneider, U.; Hauner, H. Lifestyle and Body Weight Consequences of the COVID-19 Pandemic in Children: Increasing Disparity. Ann. Nutr. Metab. 2021, 77, 1-3. [CrossRef] [PubMed]

24. Minuto, N.; Bassi, M.; Montobbio, C.; Vinci, F.; Mercuri, C.; Perri, F.N.; Cabri, M.; Calevo, M.G.; d'Annunzio, G.; Maghnie, M. The Effect of Lockdown and Physical Activity on Glycemic Control in Italian Children and Young Patients with Type 1 Diabetes Front. Endocrinol. 2021, 12, 690222. [CrossRef]

25. Cheng, H.P.; Wong, J.S.L.; Selveindran, N.M.; Hong, J.Y.H. Impact of COVID-19 lockdown on glycaemic control and lifestyle changes in children and adolescents with type 1 and type 2 diabetes mellitus. Endocrine 2021, 73, 499-506. [CrossRef] [PubMed]

26. Wu, X.; Luo, S.; Zheng, X.; Ding, Y.; Wang, S.; Ling, P.; Yue, T.; Xu, W.; Yan, J.; Weng, J. Glycemic control in children and teenagers with type 1 diabetes around lockdown for COVID-19: A continuous glucose monitoring-based observational study. J. Diabetes Investig. 2021, 12, 1708-1717. [CrossRef] [PubMed]

27. Al Agha, A.E.; Alharbi, R.S.; Almohammadi, O.A.; Yousef, S.Y.; Sulimani, A.E.; Alaama, R.A. Impact of COVID-19 lockdown on glycemic control in children and adolescents. Saudi Med. J. 2021, 42, 44-48. [CrossRef] [PubMed]

28. Turan, H.; Güneş Kaya, D.; Tarçın, G.; Evliyaoğlu, S.O. Effect of the COVID-19 quarantine on metabolic control in children and adolescents with type 1 diabetes. Endocrinol. Diabetes Nutr. 2021. [CrossRef] [PubMed]

29. Vinker-Shuster, M.; Grossman, E.S.; Yeshayahu, Y. Increased Weight Gain of Children during the COVID-19 Lockdown. Isr. Med. Assoc. J. 2021, 23, 219-222.

30. Marigliano, M.; Maffeis, C. Glycemic control of children and adolescents with type 1 diabetes improved after COVID-19 lockdown in Italy. Acta Diabetol. 2021, 58, 661-664. [CrossRef]

31. Ruíz-Roso, M.B.; de Carvalho Padilha, P.; Matilla-Escalante, D.C.; Brun, P.; Ulloa, N.; Acevedo-Correa, D.; Arantes Ferreira Peres, W.; Martorell, M.; Rangel Bousquet Carrilho, T.; de Oliveira Cardoso, L.; et al. Changes of Physical Activity and Ultra-Processed Food Consumption in Adolescents from Different Countries during Covid-19 Pandemic: An Observational Study. Nutrients 2020, 12, 2289. [CrossRef]

32. Pietrobelli, A.; Pecoraro, L.; Ferruzzi, A.; Heo, M.; Faith, M.; Zoller, T.; Antoniazzi, F.; Piacentini, G.; Fearnbach, S.N.; Heymsfield, S.B. Effects of COVID-19 Lockdown on Lifestyle Behaviors in Children with Obesity Living in Verona, Italy: A Longitudinal Study. Obesity 2020, 28, 1382-1385. [CrossRef]

33. Aguilar-Martínez, A.; Bosque-Prous, M.; González-Casals, H.; Colillas-Malet, E.; Puigcorbé, S.; Esquius, L.; Espelt, A. Social Inequalities in Changes in Diet in Adolescents during Confinement Due to COVID-19 in Spain: The DESKcohort Project. Nutrients 2021, 13, 1577. [CrossRef] [PubMed]

34. Boone, J.E.; Gordon-Larsen, P.; Adair, L.S.; Popkin, B.M. Screen time and physical activity during adolescence: Longitudinal effects on obesity in young adulthood. Int. J. Behav. Nutr. Phys. Act. 2007, 4, 26. [CrossRef] 
35. Bates, L.C.; Zieff, G.; Stanford, K.; Moore, J.B.; Kerr, Z.Y.; Hanson, E.D.; Barone Gibbs, B.; Kline, C.E.; Stoner, L. COVID-19 Impact on Behaviors across the 24-Hour Day in Children and Adolescents: Physical Activity, Sedentary Behavior, and Sleep. Children 2020, 7, 138. [CrossRef] [PubMed]

36. Paruthi, S.; Brooks, L.J.; D'Ambrosio, C.; Hall, W.A.; Kotagal, S.; Lloyd, R.M.; Malow, B.A.; Maski, K.; Nichols, C.; Quan, S.F.; et al. Recommended Amount of Sleep for Pediatric Populations: A Consensus Statement of the American Academy of Sleep Medicine. J. Clin. Sleep Med. 2016, 12, 785-786. [CrossRef]

37. WHO: Prevalence of Insufficient Physical Activity. Global Health Observatory (GHO) Data. Available online: https://www.who. int/gho/ncd/risk_factors/physical_activity_text/en/ (accessed on 9 November 2021).

38. Atkin, A.J.; Sharp, S.J.; Corder, K.; van Sluijs, E.M. Prevalence and correlates of screen time in youth: An international perspective. Am. J. Prev. Med. 2014, 47, 803-807. [CrossRef]

39. Grosso, G.; Galvano, F. Mediterranean diet adherence in children and adolescents in southern European countries. NFS J. 2016, 3, 13-19. [CrossRef] 